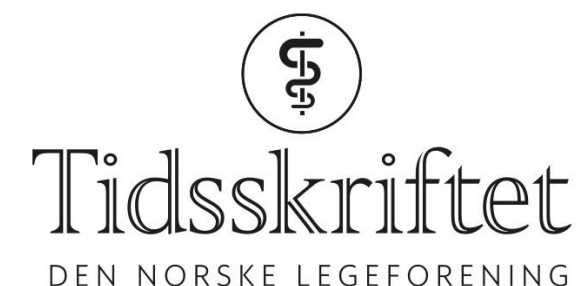

DEN NORSKE LEGEFORENING

\title{
P. Surén svarer
}

KOMMENTAR

\section{PÅL SURÉN}

E-post: pal.suren@fhi.no

Pål Surén er barnelege og forsker ved Folkehelseinstituttet.

Forfatteren har ikke oppgitt noen interessekonflikter.

Resultater fra studier fra USA - med gamle varianter av koronaviruset - er ikke et godt grunnlag for å uttale seg om betydning av skoletiltak i Norge nå, skriver Gunnar Kvåle. Han viser til en Aftenposten-reportasje hvor jeg skal ha sagt at «en ekstra effekt av hjemmeskole ikke kan utelukkes» (1).

Dette er en misvisende gjengivelse av hva jeg sa til Aftenposten. Utsagnet kom på spørsmål fra en journalist som intervjuet meg om rapporten vi nylig publiserte om smitteverntiltak i skolene (2). I avisen ble svaret gjengitt slik: «FHI har valgt formuleringen om at hjemmeskole ikke «ser ut til» å ha noen tilleggseffekt på smitteforekomsten for å ikke være for bastante, forklarer han. - Man kan jo aldri bevise noe helt sikkert i en slik analyse. Men vi ser altså ikke tegn til noen ekstra smittedempende effekt av hjemmeskole når vi sammenligner med rødt nivå.»

Det er god praksis i epidemiologien å ikke uttale seg bastant om årsakssammenhenger på grunnlag av observasjonsstudier. Men i våre analyser, som omfattet bydeler og kommuner i Oslo og Viken, fant vi ikke ekstra effekt av hjemmeskole (i betydningen heldigital undervisning) noen steder. Insidensen av nye tilfeller gikk ned overalt. Det er ingen funn $\mathrm{i}$ rapporten som gir støtte for hjemmeskole, slik Kvåle prøver å antyde.

Analysene gjelder for vinteren og våren 2021, hvor den engelske virusvarianten var dominerende i Oslo og Viken. En annen fordel var at analysene ble utført i kommuner som valgte ulike tiltak i skolene, men som ellers hadde like smitteverntiltak og sammenlignbare nivåer av smitte. Dermed ble det nærmest som et kontrollert fors $ø \mathrm{k}$ hvor vi kunne sammenligne ulike aldersgrupper innad i samme bydel/kommune, og ulike bydeler og kommuner med hverandre.

Norske data gir altså ikke holdepunkter for at hjemmeskole er nødvendig for å holde koronapandemien under kontroll. I så måte samsvarer funnene godt med den amerikanske studien (3). Kunnskap om koronaviruset blir ikke nødvendigvis utdatert selv om nye virusvarianter kommer til. 
er-smitten-me Lest 9.5.2021.

2. Folkehelseinstituttet.

https://www.fhi.no/publ/2021/evaluering-av-effekt-av-smitteverntiltak-i-skoler-februar-april-2021/. Lest 9.5.2021.

3. Zimmerman FJ, Anderson NW. Association of the timing of school closings and behavioral changes with the evolution of the coronavirus disease 2019 pandemic in the US. JAMA Pediatr 2021; 175: 501-9. [PubMed][CrossRef]

Publisert: 7. juni 2021. Tidsskr Nor Legeforen. DOI:10.4045/tidsskr.21.0403

(C) Tidsskrift for Den norske legeforening 2020. Lastet ned fra tidsskriftet.no 